Лутчин В. I., аспірант кафеери крилінального права та кримінологї Львівського національного університету ілені Івана Франка

\title{
ПОНЯТТЯ, ЗМІСТ ТА ОБСЯГ КЛАСИФІКАЦЇ̈ КРИМІНАЛЬНИХ ПРАВОРОРУШЕНЬ ЗА КРИМІНАЛЬНИМ ПРАВОМ УКРАЇНИ ТА РЕСПУБЛІКИ ПОЛЬЩА
}

\begin{abstract}
Анотація. Наукова стаття присвячена дослідженню поняття, змісту і обсягу класифікації кримінальних правопорушень за кримінальним правом України та Республіки Польща. Завдяки проведеній науковій розвідці вдалося сформувати загальне поняття класифікації кримінальних правопорушень, базовою основою для якого виступають законодавчі і теоретичні напрацювання, які знайшли своє відображення у кримінальному праві України і Республіки Польща. Також розкрито його зміст завдяки аналізу істотних ознак. Викладені наукові погляди і позиція у дослідженні мають як теоретичне, так і практичне значення.

Ключові слова: поняття, зміст, обсяг, класифікація кримінальних правопорушень, об'єктивність, чіткість, безперервність.
\end{abstract}

Постановка проблеми. У зв'язку із реформуванням кримінального права України, а саме прийняття Верховною Радою України у другому читанні 22 листопада 2018 року проекту Закону «Про внесення змін до деяких законодавчих актів України щодо спрощення досудового розслідування окремих категорій кримінальних правопорушень» від 20.04.2018 р. № 7279-д, який передбачає впровадження інституту «кримінальних правопорушень» у Кримінальний кодекс України (надалі - КК України), а також класифікацію кримінальних правопорушень на злочини і кримінальні проступки, виникає необхідність проведення наукової розвідки з метою дослідження поняття «класифікація кримінальних правопорушень». Що стосується Республіки Польща, то класифікація кримінальних правопорушень на злочини і кримінальні проступки закріплена вже доволі давно в їхньому кримінальному законі, однак у науковій доктрині практично не досліджено поняття «класифікація кримінальних правопорушень».

Аналіз останніх досліджень і публікацій. Над дослідженням поняття «класифікація кримінальних правопорушень» працювали такі вчені, як: Л. Гардоцький, А. Грешков’як, Л. Кривоченко, М. Хавронюк та інші. Однак дослідження здійснювалось у межах кримінально-правової системи однієї держави.

Постановка завдань. Метою дослідження є формулювання загального поняття «класифікація кримінальних правопорушень» за кримінальним правом України і Республіки Польща, а також визначення його змісту і обсягу.

Виклад основного матеріалу дослідження. У науковій доктрині склався сталий підхід, що під поняттям слід розуміти форму мислення, яка відображає предмети, явища, узагальнюючи їхні фактичні ознаки. Так, для визначення поняття класифікації кримінальних правопорушень за кримінальним правом України та Республіки Польща необхідно спочатку дослідити, що саме розуміється під класифікацією у вищезгаданих державах.

В українському тлумачному словнику зазначається, що «класифікація» (походить від лат. classis - розряд, клас i facio - роблю, розкладаю) - це система розподілу предметів, явищ або понять на класи, групи тощо за спільними ознаками, властивостями [5, с. 175]. У польському тлумачному словнику закріплено, що «класифікація» - це систематичний розподіл предметів або явищ на класи, види, підвиди, що здійснюється залежно від вибраного критерію [12]. Як бачимо, вищенаведені дефініції відображають однаковий підхід до розуміння цього терміна як в Україні, так і Республіці Польща.

3 точки зору філософії класифікація розглядається як загально- наукове і методологічне поняття, що означає таку форму систематизації знання, коли вся сфера досліджуваних об'єктів представлена у вигляді системи класів або груп, за якими ці об'єкти розподілені на підставі їх збігів за певними властивостями. Класифікація покликана вирішувати дві основні функції: представляти в зручному для огляду і розпізнавання вигляді всю сферу, яка нею охоплюється, а також містити в собі максимально повну інформацію по своїх об'єктах [3, с. 225].

Також варто розглянути погляди на класифікацією, які існують у логіці (наука про закони та форми, прийоми та операції мислення, $з$ допомогою яких людина пізнає навколишній світ). Класифікація є особливим видом поділу, що являє собою розподіл предметів по групах (класах), за якого кожен клас має своє постійно визначене місце. Метою класифікації є систематизація знань, тому від поділу вона відрізняється відносно стійким характером і зберігається тривалий час [11, с. 85-86]. Крім того, класифікація утворює розгорнуту систему, де кожен об'єкт поділу знову ділиться на нові об'єкти, розгалужуючись на безліч класів, що закріплюються зазвичай в таблицях, схемах, кодексах. 3 розвитком знань класифікація, як правило, змінюється, доповнюється, іноді замінюється новою, більш точною. Тому ні до однієї класифікації не можна підходити як до завершеної. Необхідно враховувати, що і сама дійсність, і знання про неї перебувають у безперервному процесі зміни і розвитку [1, с. 57-58].

Що стосується правової класифікації, то їі потрібно розглядати як спеціальний метод, правильне застосування якого сприяє правовому регулюванню, також як один із прийомів законодавчої техніки, який використовується у створенні нормативно-правових актів і дає можливість краще систематизувати їхні положення.

Повертаючись до поняття класифікації кримінальних правопорушень, варто зазначити, що у Республіці Польща, як і в Україні, під цим поняттям розуміють розподіл кримінальних правопорушень на групи за певними критеріями [6, с.113]. Такий підхід не зовсім точно відображає зміст і сутність цього терміна.

На нашу думку, класифікація кримінальних правопорушень - це об'єктивний, безперервний, чіткий розподіл кримі- 
нальних правопорушень на взаємовиключні групи за певними ознаками, які відповідають цілям класифікації, мають вичерпний характер і відображають закономірності розвитку інституту кримінальних правопорушень. Таке визначення цілком підходить як для українського, так і польського кримінального права.

Що стосується змісту поняття, то під ним розуміється сукупність істотних ознак, які містяться у дефініції, за допомогою яких і розкривається зміст. Для з'ясування змісту вищенаведеного поняття необхідно розглянути його ключові ознаки.

Однією з істотних ознак класифікації кримінальних правопорушень є об' сктивність. Вона означає, що класифікація зумовлена всебічністю і конкретністю, тобто явища пізнаються такими, якими вони є насправді. Об'єктивність відображає матеріальну ознаку кримінального правопорушення, що виражає його сутність і соціальну природу в поєднанні з об'єктивністю завданої суспільним відносинам шкоди. Матеріальність полягає в тому, що кримінальним правопорушенням може бути лише суспільно небезпечне (суспільно шкідливе за польським кримінальним законом) діяння. Не є кримінальними правопорушеннями діяння, які формально підпадають під ознаки кримінально караних діянь, передбачених у Кримінальному кодексі Республіки Польща (надалі - КК Республіки Польща) і КК України, однак через малозначність не становлять суспільної небезпеки (суспільної шкоди).

Наступною ознакою, яку слід розглянути, є безперервність, що характеризує відсутність розривів у переході від однієї групи, категорії до іншої, зберігаючи певну послідовність. Вона дає змогу визначити ту грань, яка існує об'єктивно між кримінальними правопорушеннями різних груп, категорій, а також між кримінально-протиправними діяннями та іншими правопорушеннями, які перебувають поза межами кримінально-правового регулювання. Особливо актуальним $€$ питання розмежування кримінального проступку та адміністративних правопорушень. Розглядаючи це розмежування в рамках польської правової системи, насамперед слід зазначити, що кримінальний проступок (występkiem) регулюються Кримінальним кодексом Республіки Польща (Kodeks karny), a адміністративні правопорушення (wykroczeniem) регулюються Кодексом адміністративних правопорушень Республіки Польща (Kodeks wykroczeń). Кримінальний проступок і адміністративні правопорушення є діяннями, забороненими законом, за які винна особа несе відповідальність, однак другі завдають набагато меншу шкоду суспільним відносинам, відповідальність за них набагато м'якша. Ключовою підставою розмежування служить вид і міра покарання. Так, за адміністративні правопорушення передбачена така відповідальність: 1) арешт від 5 до 30 днів; 2) обмеження волі до одного місяця; 3) штраф від 20 до 5000 злотих; 4) догана [9]. Що стосується кримінальних проступків, то за них передбачена така відповідальність: 1) штраф у розмірі понад 30 денних ставок або більше 5000 злотих; 2) обмеження волі від одного місяць до двох років; 3) позбавлення волі від одного місяця до трьох років [7]. Процес, спрямований на притягнення особи до відповідальності, передбачається різними нормативними актами. Так, у справах про кримінальні проступки застосовується Кримінально-процесуальний кодекс Республіки Польща (Kodeks postępowania karnego) [8], а у справах про адміністративні правопорушення Адміністративно- процесуальний кодекс Республіки Польща (Kodeks postępowania w sprawach o wykroczenia) [10].
Ще однією істотною ознакою є те, що класифікаційні групи мають взасмно виключати одна одну. Насамперед це означає, що кожна група кримінальних правопорушень має відрізнятися від іншого своїми специфічними рисами, притаманними саме їй. Вчинення кримінального правопорушення певної групи, категорії має тягнути юридичні наслідки, відмінні від наслідків, встановлених для інших. Наприклад, передбачена у арт. 7 КК Республіки Польща класифікація кримінальних правопорушень на дві групи: злочини і кримінальні проступки, відіграє важливу роль під час визначення строків давності, передбачених в арт. 101 § 1 КК Республіки Польща, де закріплені різні строки давності для кожної групи (різні юридичні наслідки). Так, під час скоєння злочину строки давності становлять 30 років (за умисне вбивство) і 20 років (за всі інші злочини), що стосується кримінального проступку строки коливаються від 5 до 15 років (15 років - коли діяння являє собою кримінальний проступок, за який передбачено покарання у вигляді позбавлення волі на строк більше 5 років; 10 років - коли діяння являє собою кримінальний проступок, за який передбачено покарання у вигляді позбавлення волі на строк більше 3 років; 5 - коли йдеться про інші кримінальні проступки) [7]. Як бачимо, для визначення строків давності необхідно класифікувати кримінальні правопорушення на злочини і кримінальні проступки, а також провести ще й додатково класифікацію кримінальних проступків залежно від виду і розміру покарання, передбаченого в санкції відповідної кримінально-правової норми. Що стосується українського законодавства, то проект Закону «Про внесення змін до деяких законодавчих актів України щодо спрощення досудового розслідування окремих категорій кримінальних правопорушень» від 20.04.2018 р. № 7279-д, прийнятий у другому читанні Верховною Радою України 22.11.2018 року, пропонує закріпити в статті 49 Кримінального кодексу України такі положення, за яких особа звільняється від кримінальної відповідальності, якщо 3 дня вчинення нею кримінального правопорушення і до дня набрання вироком законної сили минули такі строки:

1) два роки - у разі вчинення кримінального проступку, за який передбачене покарання менш суворе, ніж обмеження волі;

2) три роки - у разі вчинення кримінального проступку, за який передбачене покарання у виді обмеження волі;

3) п'ять років - у разі вчинення нетяжкого злочину;

4) десять років - у разі вчинення тяжкого злочину;

5) п’ятнадцять років - у разі вчинення особливо тяжкого злочину.

Як вбачається з вищенаведеного, для визначення строку давності за те чи інше кримінально каране діяння, виникає необхідність класифікації кримінальних правопорушень на злочин і кримінальні проступки, своєю чергою злочини необхідно класифікувати на нетяжкі, тяжкі, особливо тяжкі. Саме таку класифікацію пропонує закріпити вищезгаданий законопроект у статті 12 КК України [4].

Чіткість як істотна ознака класифікації кримінальних правопорушень свідчить про те, що вона має бути підпорядкована насамперед практичному використанню. Класифікація має проводитись за такими критеріями, які 6 унеможливлювали іiі двозначне розуміння. В одній і тій ж класифікаційній групі необхідно застосовувати одну і ту ж класифікуючу ознаку. У класифікації кримінальних правопорушень ця ознака має величезне значення, оскільки правоохоронним органам 
доводиться на практиці розмежовувати по групах (категоріях) кримінальні правопорушення. На думку Л.Н. Кривоченка, вищезгадана ознака має важливе значення, позаяк правильне визначення певної групи, категорії, до якої належить конкретне кримінальне правопорушення, визначає рамки його юридичних наслідків, а отже, є основою для справедливої відповідальності конкретної особи. Також, на його думку, класифікація кримінальних правопорушень має випливати 3: 1) внутрішніх зв'язків, які існують між ознаками кримінальних правопорушень, що надають їм певну цілісність і утворюють той чи інший вид кримінальних правопорушень; 2) зовнішніх зв'язків окремих видів кримінальних правопорушень між собою; 3) зв'язків i взаємовідношень кримінальних правопорушень 3 іншими правопорушеннями (адміністративними, цивільно-правовими, дисциплінарними та ін.) [2, с. 18].

Обсягом поняття називається сукупність предметів, які охоплюються цим поняттям і містять його істотні ознаки. Обсяг поняття «класифікація кримінальних правопорушень» у цьому науковому дослідженні охоплює всі можливі класифікації кримінальних правопорушень, які існують у кримінальному праві України і Республіки Польща. Сукупність предметів, що становлять обсяг поняття, називається логічним класом. Клас може включати в себе підкласи. Наприклад, клас «класифікація кримінальних правопорушень за кримінальним правом Республіки Польща» включає в себе підклас «класифікація кримінальних правопорушень на злочини і кримінальні проступки». Кожен такий підклас утворюється за певною ознакою, притаманною тільки йому.

Зміст і обсяг поняття тісно пов'язані один з одним, цей зв'язок виражається в законі зворотного відношення між обсягом і змістом поняття, який встановлює, що збільшення змісту поняття призводить до зменшення його обсягу, і навпаки. Так, наприклад збільшення змісту поняття «класифікація» шляхом додавання ознаки «кримінальні правопорушення» ми переходимо до поняття «класифікація кримінальних правопорушень», яке за обсягом є меншим [1, с. 35-36].

Висновок. Підбиваючи підсумки у науковому дослідженні, варто зазначити, що викладені підходи і позиції допоможуть краще зрозуміти сутність і зміст класифікації кримінальних правопорушень, оскільки випливають із законодавчих і доктринальних позицій, які існують у кримінальному праві України i Республіки Польща. Також можуть бути використані у здійсненні класифікації кримінальних правопорушень на практиці.

\section{Jimepamypa:}

1. Кириллов В.И., Старченко А.А. Логика: учебник для юридических вузов / под ред. проф. В.И. Кириллова. 6-е изд., перераб. и доп. Москва: Проспект, 2008. 240 с.

2. Кривоченко Л.Н. Классификация преступлений. Харьков: Вища шк. Изд-во при Харьк. ун-те, 1983. 129 с.

3. Новая философская энциклопедия. В четырех томах. / Ин-т философии РАН. Научно-ред. совет: В.С. Степин, А.А. Гусейнов, Г.Ю. Семигин. Москва: Мысль, 2010. Т. ІІ. 2816 с.

4. Проект Закону про внесення змін до деяких законодавчих актів України щодо спрощення досудового розсліду- вання окремих категорій кримінальних правопорушень від 20.04.2018 р. № 7279-д. URL: http://w1.c1.rada.gov.ua/pls/ zweb2/webproc4_2?id=\&pf3516=7279-\%E4\&skl=9 (дата звернення 05.12.2018).

5. Словник української мови: в 11 томах. Том 4, 1973. URL: http://sum.in.ua/s/klasyfikacija

6. Grześkowiak A.(red.), Wiak K. (red.) Prawo karne. Wydanie 6 . Warszawa: C.H. Beck, 2017. 437 s.

7. Kodeks karny: Ustawa z dnia 6 czerwca 1997 r. Kancelaria Sejmu. 1997. Nr 88. poz. 553. $135 \mathrm{~s}$

8. Kodeks postępowania karnego: Ustawa z dnia 6 czerwca 1997 r. Kancelaria Sejmu. 1997. Nr 89 poz. 555. 294 s.

9. Kodeks wykroczeń: Ustawa z dnia 20 maja 1971 r. Kancelaria Sejmu. 1971. Nr 12 poz. 114. $51 \mathrm{~s}$.

10. Kodeks postępowania $\mathrm{w}$ sprawach o wykroczenia: Ustawa $\mathrm{z}$ dnia 24 sierpnia 2001 r. Kancelaria Sejmu. 2001. Nr 106 poz. 1148. 58 s.

11. Malinowski A., Lewandowski S., Machińska H., Petzel J. Logika dla prawników / pod redakcjà A. Malinowski. Wydanie 7. Warszawa: LexisNexis, 2012. $319 \mathrm{~s}$.

12. Słownik języka polskiego / pod red. W. Doroszewskiego. Warszawa: Wydawnictwo Naukowe PWN. 1958-1969. T. I-XI. URL: http://sjpd.pwn.pl/haslo/klasyfikacja/

Лутчин В. И. Понятие, содержание и объем классификации уголовных правонарушений по уголовному праву Украины и Республики Польша

Аннотация. Научная статья посвящена исследованию понятия, содержания и объема классификации уголовных правонарушений по уголовному праву Украины и Республики Польша. Благодаря научному исследованию удалось сформировать общее понятие классификации уголовных правонарушений, базовой основой для которого выступают законодательные и теоретические наработки, которые нашли свое отражение в уголовном праве Украины и Республики Польша. Также раскрыто его содержание благодаря анализу существенных признаков. Изложенные научные взгляды и позиция в исследовании имеют как теоретическое, так и практическое значение.

Ключевые слова: понятие, содержание, объем, классификация уголовных преступлений, объективность, четкость, непрерывность.

Lutchyn V. Definition, content and amount of criminal offences classification under criminal law in Ukraine and in Polish Republic

Summary. This scientific article is devoted to the research of definition, content and amount of criminal offences classification under criminal law in Ukraine and in Polish Republic. Due to the conduct of scientific research, it was possible to form general definition of criminal offences classification, the basis of which are the legislative and theoretical work, which are reflected in the criminal law of Ukraine and the Republic of Poland. Due to the analysis of essential features of criminal offences classification, the content of criminal offences classification was revealed. Presented scientific views and position in the research have both theoretical and practical significance.

Key words: definition, content, amount, criminal offences classification, objectivity, clarity, continuity. 